\title{
Developmental Reaction Norms: the Interactions among Allometry, Ontogeny and Plasticity
}

\author{
MASSOMO PGLUCCI, CARL D. SCHLICHTNG, CYNTHA S. JONES and KUAT SCHWENK

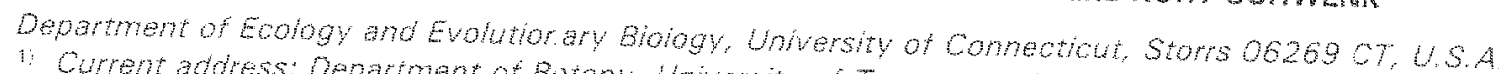 \\ 1. Curent addess. Deparment of Butany. Unversity of Tennesse. Knoxvile, TN. U.S.A.
}

\begin{abstract}
How mico and macroevo utionary avolutionary processes produce phenotyplo change is without ques.

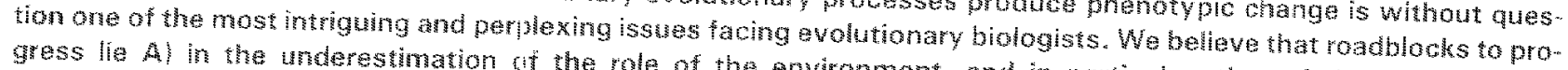
gress lia Al in the underestmation at the role of the envirommen, and in particular, that of the interaction of tionary synthesis. We propose the integraton of continuing lack of incorporation of development into the evoluavolution of the phenotype in the form of the of genetic, environmental and developmental perspectives on tha

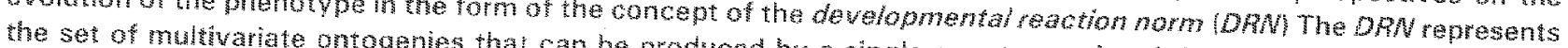
variation. It whompasses: 11 the processes broduced by angle genotype when it is axposed to environmental recognition that diterent aspects of the phenotyper the phenotype thoughout the ontogenetic trajectory, 2 h he

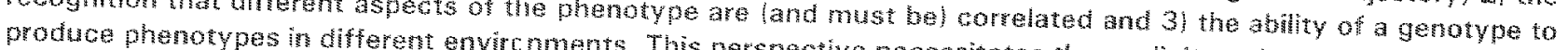
sion dumg development, the evaluation of associstionsectve necestitates the axplicts study of character expresallometresl, and the axploration of rean of associations betwoen pairs or groups of characters (e.g. multivariate DhN to encompass adjustont of rastion noms and phenotypie plasticity. We explicity axend the concept of the

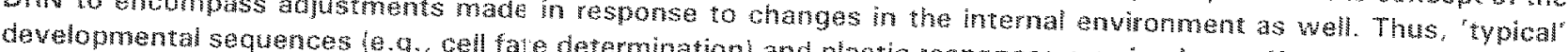
scales of emirommental' effec long determmation and plastic responses are simply mantestations of different aspects of the gersaration and along a conthum. We present: (I) a brief conceptual review of three fundamental ferentation (ontogeny), the mulvariate relationships among changas in the trajectories describng growth and dif. ment (plasticity): (2) a dscussion of how thesonships among characters lallometryl, and whe aftect of the anvironnom: and (3) a reaction norm perspective components ara merged in the concept of the developmental reaction straint.
\end{abstract}

Key words: phenotypic evolution, eaction nom alometr, development, ontogeny, heterochrony. pasticiy, constrant, epigenerics, selection.

Evolution is ultmately defined at the ge rotypic level as the ensemble of processes that causes changes in allele Fraquencies. Yet, arguably the most fascheting aspect of evolutionary blology is the bewhdertrg diverity and complexity observed at the phenotyplevel. Gven the only vaguely understood rebtonship between geno. types and phenotypes, the evolutonary nodifteaton of the phenotype remains one of the most intrigung problems in modem evolutonary biology. Dur limited understanding stems from several diferent sources: the myriad genetic programs being carred out in the differ. ent tissues of a lwing organism and the vecessty of integrating the products of such programs: the capacty of epigenerc systems to magnify the ef ects of simole genetic changee, or minimize effects of major ones; and the mallebility of the developmental orocesses in the face of aterations in environmental conditions.
We believe that a comprehensive vew of phenotypic evolution must explicity incorporate three aspects of phenotypic expression: genetics, development and anvironment. A phenotyperesuls from a complex and in. extricable interaction between genes and environments throughout developmental time. Any given characterstic of an onganism is the product of interections among those genes and trats expressed durng anler stages, and the constructon of a phenotype cannot be uncoupled trom the particular enviroment in which thas developed. In this paper we combine the perspectives of genetios, development and emviroment in a repre sentation of the phenotype we refer to as a develoomental nom of reaction, is. the set of ontogenies that can be potentilly produced by a single genotype when it is exposed to dfferent enviromments. The development reaction nom encompasses: the processes that ater the phenowpe throughout the ontogenetic trajectory the recogntion that diferem aspects of the phenotype are land must bel correlated; and the abilty of a genotype to produce phenotyes in differat enviroments. We see thres fundamental concepts arisng from or congruent with this perspetve: 
of three fundamental aspects of the generation and evolution of phenotypes: the changes in the traiec tories describing growth and dfferentation lontogeny) the mutvarate relationships among characters (allometry, and the effect of the enviroment folastcityl, 12 a discussion of how, for a more comprehensive understanding of phenotyplc evoution, these com. ponents are being and should be merued in the concept of the developmental reaction nom: and (3) a reaction nom perspective of wo malor determinants of phenotypes: ppigenesis and constraints.

\section{Histoncd Overvew}

The concepts of changes in the ontogenetic tralectory. correlations among onaracters, and response to difer. ent anvitonmental conditions, which we combine into the defintion of the davelopmental peaction nom, are not new. In fact, they all were proposed by the end of the last century or the beginning of this one. For histori cal and technical reasons, however, thay have not been discussed within a common framewor, and the fow at tempts to introduce them into the cur ent paradigm of evolutionary biology have faled until rectimes (Got theb, 1992; Hall 1992; Rollo, 1994)

Thee authors made significan. contributions towards the synthesis that we are advocating and they have been generally grored, dimised or considered as interesting paculianties for hal a century. Historicaly, ideas simiar to some of hose portrayed here were maturing by the and of the 1930 's or the beginning of the 1940 s in the work of three resear. chers: R. B. Goldschmdt in Germany, I, Schmahausen in Russia, and C.H. Waddington in England.

In 1940 Goldschmid published his very controversial book, The materia basis of evoluton, atacking the nas cent 'modern' evolutionary synthesis on the basis that neodarwinism provided a parochial explanation of evolution, limited to microevolutionary phenomena Goldschmit, 1940). For him, the real challenge was explaining the evolution of new species and especially new body plans, a chalenge he felt was clearly beyond the limits of the theoretical framework of Dobzhansky. Mayr and Simpson. His vew of macroevoluton, how. ever, was much more comprehenswe tran the tyolcal caricature of the "hopeful monster". He argued for a maior role of chromosomal rearangement; on the basis that, given the complexity of phenotypes, only such rearrangements of the already axisting pleces were likeIy to bring workble atemative solutions to the mor phology of an organism.

Golischmidt revewed axamples of envirommentalyinduced phenotypes mimicking known mutations the coned the term phenocopy for such casesi, which in his vew are a phenomenon of general biologicalmportance, because they provide hints about gene action. If a mutation behaves exacty in the same way as the phenocopy, it is logical to conclude that this mutation induces a similat effect: the affected genels) work faster or slower. Goldschmidt also considered how the internal enviroment affects the creation of phenotypes, discussing in particular what was then known about homonal action. He concluded that the regulatory action of both extemal and internal environments can produce astonishingly different phenotyes in geneticaly very imilar backgrounds.

Goldschmidtinaly discussed the effect of mutations on early development. He uses examples of the currentY fashonable homeosis as a major explanation of how developmental mutants can rigger the production of radically altered phenotypes. The emphasis on action early in development was based on de Beer's 1940 ) ldea that characters are much more interrelated at the beginning of the ontogenetic trajectory: mutation and selection acting at those stages would certainly be much more effective in reshaping the entire phenotype (Stebons Jr. 1950; Arthur, 1988). This pont has also been reamphesized recently by West Ebehard (1989). and expenmentally supported by Atchey 119841 , but see Raff ot al. 1991; Wray, 1992, 19951.

Schmahausen 1949 published his main contribu. tion to svolutionary biology under the tite factors of evolition the theory of stabiling selection. His basic idea is simple and powerul avolution is the process of how the developmental systems of ling organisms are atered to change the nom of reaction to initially cope with, and later anticipate, the environmental stimuli. Schmahousen begins by delining and discussing the concept of norm of reaction. He directs our atiention to the mantold effects of mutation and to their environ. mentaly induced variability in expression here coming close to the idea of phenocopy so clearly expressed by Goldschmid. He then introduces wo important concepts: the distinction between a labie and a stable organism (I.e. a plastic and a non-plastic onel: and the idea of a "nomal phenotype", the result of past directional selection, and currenty maintaned by what he termed stablizing selection, the selection against ex. treme phenotypes. A "new" nom of reaction arises in itialy beceuse envirommental changes expose a different portion of the existing reaction norm. There is then selection for mutations that improve the norm of reac. tion in the drection of the environmental change. followed by stablizing selection on the new norm of reaction.

Schmahausen emphasized that this secuence of avents imples the shif from a resction to the environ. ment due to differential aleic sencitivity (a simple result of the biochemisty or physology of the organism, to a more complax regulatory aystem. This system s capable not only of changing with the environmental conditions, but of antioling the environmental demands like the humidy-drwen switch in meny semi-aquatic plants between linear and dissected leaves, or the photoperiodinduced abscission of leaves 
in many deciduous plants

Waddington's ideas on development and evolution appeared in defintive form much later than the other wo authors The strategy of the yenes. Waddington. 1957 , but his basic intutions and the experments sup. porting them were publshed starng from the early 1940 . Central to the way in which Waddington perceives development is the idea of candization: the tendency of a genotype to follow the same developmental path even in the face of intemal or external per turbations. Canalization, in his conception, is clearly the result of natural selection, and rom both its defin. thon and the examples portraved to support it 16.9 . anvirommentaly cued metamorphosis in amphibians, heterophylly in plante, the concept of calalizing selection is very simlar to the idea of stabiling selection on the new nom of reaction proposed by shmahausen who acknowledged profound simlarites betwen his think. ing and Waddington's. The process described by Schmahausen of change from the old nom to the new one through an intially enviromentaly-induced response is bastolly Waddington's notion of generic assimilation Waddington's later artempt 19611 to distn. guish the two notwithstandingl. In fuct, genetic assimlation was orgmally defined as the process by which a phenotypic character initialy prodused as a response to some enviromental influence, is stabilzed due to natural selection and hally ocours even in the absence of the previously necessary extemal influence Waddington, 1942). This is an explict vew of reaction noms as the objects of selection.

Waddington demonstrated the ocurrence of genetic assimilation with his famous series of experiments on Drosophila stbjected to heat shock curing laval devel. opment. He began with a srock of hiks that produced a novel phenotype in low frequency when subjected to heat shock at an early larval stage. After several genera. tions. he observed the appearange of the novel phenotype in the absence of the hur shock Waddington, 1952, 1953, 1959. He late generdized such findings to different traits and enwonmental stmuli (Waddington, 1961).

\section{Cument Approaches to phenotycic Evolution}

The conceptual framework proposed by Goldschmid, Sohmahausen and Waddington has not been incorporated into current modals of phenotypic evolution. Most of these have been derived from the statstical-genetic underpinnings of the modem synthe. sis establehed by Fisher, Wright and Haldane and pro. mulgated by Dobzhansicy, May and simpson. The emphesis in early models and their current elaborations has been on simple genetic systers-mosty many alles with small addive effects. Ona man reason for this emphasis is that the mathematcal treatment of these systems can be based on sets of smple linear equations, which allow anaytical solitions of general validiry. Few explicit attempss have been made to in. clude development and epigenetics into these models because they introduce non linear effects leading to mathematical intractability and solutions that are not generalzable.

There are wo main current approaches, oprimization modelling and quantitative genetics. Although optimization models alow the finess function lie., the mapp. ing of phenotypes onto fitness, or the adaptve land. scape) to chenge depanding on the conditions of the population le.g. frequency-dependent selection, their major limitation is that they do not address at all the ge. netic basis of phenotypic bvoluton. These models assume thet the genetic variation necessary for selection to operate will be present in the population. This imples that there are no genetic constrants land thus no development or eplgeneticsi and that phenotypic evolution is governed only by conflcting selective pressures.

Quanthative genetics, on the other hand, specifies a particular genetic besis for phenotypes. but generally assumes both temporal and spotial constancy of the ge. neto variance-covarianca math $x$, and of the htress surface lie., the relationship between character states and thess is fixed. Also, the genetio system govem. Ing phenotypic trats is assumed to be very simple but see Barton and Turell, 1989. These Imitations have been recognized Turell, 1988, Schichting and Piglucc. 19958 , and attempts have been made to merge the two approaches Roff, 1994). However, as Charlesworth 1990 argued a simple mapping of genetic constrants quantitatie genetics) onto functional Imitations (optimization models) is possible only in very simple situations $(0.9$. the case of two traits govemed by a tradeoft based on a negative genetic correlation. Additionally, when we consider a complex multvariate phenotyoe, simple genetic corratans are not necessarly reliable indicetors of functional constraints or tradechs anymore, ss pointed out by Houle 19911.

Other attempts have been made to include a more complex view of the phenotye within the guantitative genetics framework. Although explicity recognizing the role of developmental processes in evolution le.g. Atchey and Hall, 1991; Cowey and Atchey, 19921, the inclusion of more statistical terms le.g. "epigenetic" components into the model does not address the fundamental issues pither. What is needed is a mechanistic analysis of mow variation arses and is Htered through development: selecton operates throughout the life cycle, and a vew limited to the adut phenotype is therefore ineufficient to account for th effects in shaping phenotypic evolution. From this point of view, one problem with the current synthesis is an imbalance beween an emphasis on population-eve phenomena (dealng with how noveltes spread) vs. i.:dividuallevel processes (dealng with the origin of phe. notypic novelties. 
Developmental Reaction Noms: Allomestry, Ontogeny and Plasticity

Coined by Woltereck in 1909 Wotereck, 1909, the term reaction nom defines a sute of phenotypes potentialy ar actualy produced by a single genotype when the development occurs in a given range of enviroments. It is interesting to note that Woltersck us. ed the exigtence of reaction noms a an argument against the concept of the genotype Uohannsen. 19111 . From a practical stancpoint, leaction norms can be measured as average responses of genotypes. populations, or species, depending on tha level of analy. sis one interested in lmuch in the sams way that simple character means measured within an environment can be averages at any of the same levelsl.

The deteminans of the reacton nom that we wil consider are: (a) ontogenetic trajectories, describing the unfolding of the developmental program: (b) alometry, measuring the relationshos among in. dividual trats of the whole organism; ard (c) plasticity. as a measure of the magnitude and pattem of the response to the extemal environment.

\section{Ontogeny}

The ontogeny of an organism includes all events, both cuantitative and qualtative, ocurring from the single cell through the adult stages. As a field of a study, de velopmental biology is much older than svolutionary bi. ology itself, and its practioners have seen interested in not only documenting pattens, but in identhying general rules for the production of organismal form. as well as evolutionary relationships. It is, however, a field in rapid expansion because of the very recent advances of molecular developmental genetics in both animal and plant model systems 16.g., Akam at al, 1994 bl.

The quantitative events that ocur during the ontogeny of an individual (e.g., increase in size) can be visualized as an ontogenetic trajectory (Aberch et al. 1979), with the qualiative events (e.g. differentiation. metamorphosis, etc. corrasponding to particular points on the trajectery (6.9. Creighton and Strauss. 1986; Strauss, 19901. The tralectory can be described mathematicaly, usually by means of a sigmoidal function lathough other functions may be used as well IFig. 21. As the link betwesn the genes and the adut phenotype, ontogeny represents the ensemble of procsses by which local genetic rules are translated into functional phenotypes, that is the epigenetio system.

\section{Allowetry}

Allometry is a concept orginaly developed by Huxley $(1932)$ in reference to the proportionel growth of one character ralative to a second character $(e . g$. changes in aspects of the horse skul (Radinsk, 1984), or to some measure of overall organbody size le.g.

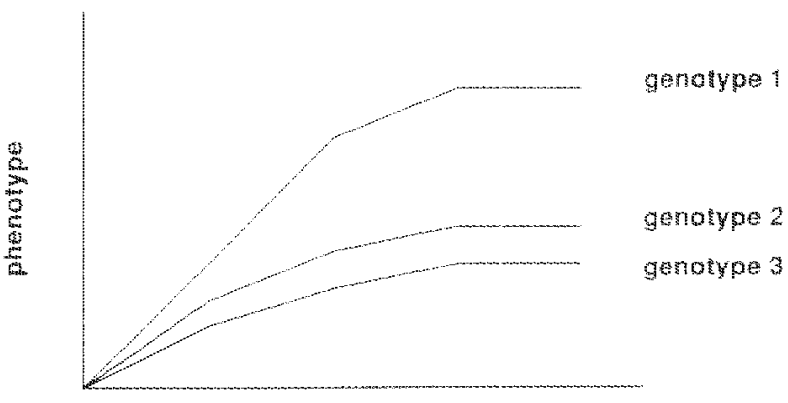

developmenta lime, in one entironment

Fig. 2. A depiction of the ontogenetic majectories of three genotypes grown in a single enviroment. The phenotypic trat increases through time, eventwaly reaching a constant value at maturity. Genotye I has a steeper growh tracoiory, and anhieves a larger find size.

brambody size: Lande. 1979). In Huxley's view, allometry referred spectically to phenomene in which the rate of growth of one feature does not equal the rate of growth of the second feature li.e. the allometric cofficient is greater than or less than onel, in contrast to isometry, which represents the spectal case where two features increase in size at axacty the same rate (i.e., the allometrio coefticient equals onel. Huxley's description has since ben generalied lCock, 1966 ; Gould, 1966: Cheverud, 1982, to include regression analyses based on measures on multiple individuals taken at a specific developmental stage, often maturty (static allometry: Fig. 3), ar well as on species means along a phyogeny (evolutionary alometry. Alometric associations have been used to infer shared develop.

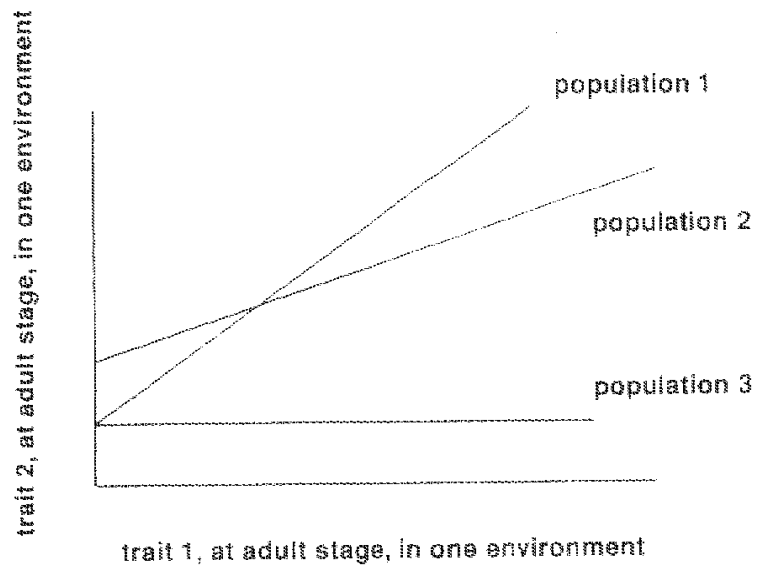

Fig. 3. A representation of statc alometry at the adult stage h a ange erwhonment. The three populations difer in the relatonshios between trats 1 and 2 Populations 1 and 2 show a postive relationship, whereas in populaton 3 . there is no comelation betwean the wo rats. 
mental mechanisma and to examine evolutionary phenomena underiying the observed pattems.

The empirical study of allometry allows us o deter. mine how characters are correlated and therefore potentialy integrated into the whole phunotype. Recently, the idea of phenotypic integration tas been at the center of increasingly sophisticated multivariate aporoaches to the study of alometry (e.g., Jicoeur, 1989; Klngenberg and Zmmemann, 1992; $\mathrm{K}$. ingenberg and Spence. 1993), It is now ponsible to describe the complex interelationships among many trats simultaneously, as well as the variation in natural populations for the way integration is acheved.

\section{Plasticity}

The concept of phenotypic plasticity is so righty connected with the ldea of reaction nom that the two are often considered to be synomymous, although they are technicaly distmct. The idea of reaction noms is as old as the distinction between genotype and phenotype in. troduced by Johanssen $(1911)$ at the beginnirg of the century. It was greaty elaborated by schmahausen $(1949)$ and brought agan to the evolutionary debate by Bradshaw 1968 , followed more recenty by anm ber of other researchers la.g. Shlichting. 1986; Sutan, 1987: Steans, 1989: West Ebemarc, 1989: Schichting and Pighuco, $1995 \mathrm{bl}$.

Conceptualy, the raction nom can be imag ned as a genotype-specific tunction defined on a cartesian plane with some measure of the ervironment on the abscissa, and a measure of the phenotypic trat on the ordnate (Fig. 4). Plasticity is a particular atribute of the reaction nom describing any case in which the reacthon norm of a genotype is not flat li.e., it is not a ine parallel to the environmental axist. There are currenty two classes of phenotypic plasticity recognized ISmithGill, 19831: phenotypio modulaton, where the plastic

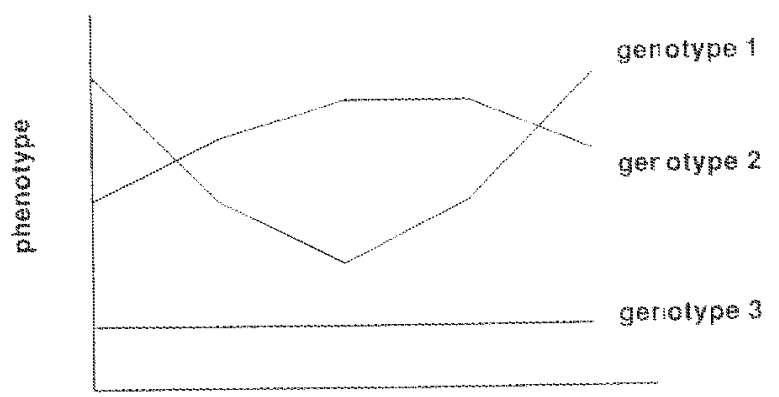

enviroment a one developmental stage

Fig. 4. A typlcal raction nom diegram representig the exoression of a smole phenotypic trat 6.9. plant height measured ane pont in time in everd onvironments te.g.

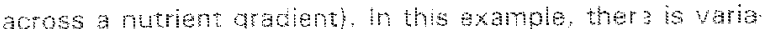
ton emong the three genotypes: 1 and 2 deplan diferent plastic responses. While 3 is non plastio. responses are a continuous and proportional function of the environmenal stmulus le.g., plant height in. Fuencad by mutrent avalablity, water of light; thorax length in orosopha intuenced by temperature and developmental comerson, whare responses are of a theshold type and are not proportional to the stimulus le.g. an initial envionmental cue triggers a series of developmental events in the organism such as gemmathon, fowering, shade avoldance response, and heterophyly in plantsl.

Emplically, reacton nom plots alow the researcher to trace the wav diferent genotypes respond to a given sat of envitonmental changes le. G. Gupta and Lewonthi 1982). The spread and amount of crosing of the reacton noms in such diagrams ffig. 4is a representation of the genetic variation for character means and plastic responses in the given population lde Jong. $1995 \%$

\section{Allometry and ontogeny}

The first twoway Interation among the three basic concents lust reviowed is that between allometry and ontogeny. Alometry is often measured as a developmentaly static entity, usualy using date from adur indviduds: at tha same time most publshed papers on ontogenetic rajectoriss consider one character at a time. If we combine the wo perspectives (Fig. 5), we appreciate that allomeric cofficients can show complex dynamics throughout ontogeny. as recenty ponted out by aumber of authors inragavesev and Utemshev, 1975; Zeldich, 1988; Kelogo, 1990; KL ingenoero and Zimmemann, 1992; Jones: 1993; K.

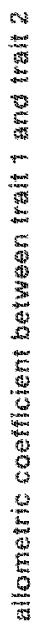

Fio. 5. Combining amotry and onmony: a representation of the relatonhw bewan trats te. phant hegh and new leaf production as a function of developmental time. messured in angle enviroment. The wo trats have a constantelatonshe for popudion thoughout development. but the retathohp changes in each of the other popula. rions. 
inganberg and Spence, 1993; Bonser and Aarssen. 1994). For example. Piglucel et (19. (1996) found for Lobelia siphitica grown under high nutrients that the correlation between leaf production and plant height declined from 0.63 to 0.02 betwen the fourth and tenth week of development.

The study of such diagrams yidds a better understanding of how phenotypic integration in the adult is forged throughout development. Furthemore, in this way it is possible to pinpoint pericds of the ontogeny when the correlation between two tratts is stronger or weaker, If this corrstation has a genetic basis, this means that there will be more or less favorable oppor. tunities for selection to act, depending on which ontogenetio stage is going to be afected by salective pressures las has been ponted out by Archey, 1984 ). The detalled knowedge of the occurence of such "whdows" can add an entrely new dimension to the evolutonary consequences of character corretations as wel as point to altemative strategies of plant or animal breeding le.g. in cases in which che wants to apply selection on wo traits in a drection that would be op. posed by the existing correlation at the adult stagel.

\section{Alometry and plasticty}

The connection between alometry and plasticty opens the way to the understanding of the other side of varia. ton in alometric coeficients: their enviromental dependence. Alometry is usualy measured in a single environment "common garden" conditions), the intent being to characterize the genetic variation in phenotyp. ic correlations, leaving out "envirmmental noise". At the same time, plasticity is usualy studied on single characters, with reaction noms for separate trats plotted aganst the environmental varis elsl and then compared in a qualtatve way. Howevar, we now know that both phenotypic and genetic correlations land therefore alometrio coefficients moy change dramatically when the same set of genotypes is raised in different environments Llechowicz and Blas, 1988; Schlohting, 1989a, b. Steams et al, 1991; Platenkamp and Shaw, 1992; Thompson. 1992; Andersson and Shaw, 1994: Bonser and Aarssen, '994; Miller et al. 1994: Schmid and Dot, 1994: Whdig, 1994; Cheplick, 1995: Hakkaranen and Korpmaki, 1995: Piglucoletal, 1995: Schlchting and Pighuce; 1995b). For example, in the previously mentioned study on Lobelia Plglucei et al. 1996), the correlation of leat number and heignt at week ten wais 0.02 in the high nutrient treament, but 0.86 under low nutrients.

These knds of data tell an andogous story to the one related by the ontogenetic changes of alometric coefficients: allometry is not an invariant property of certain characters, It can be altered when the environmental conditions are changed ifig. 6 . This hes again both evolutionaty and practical consequences on the correlated response of several trats to selection, which

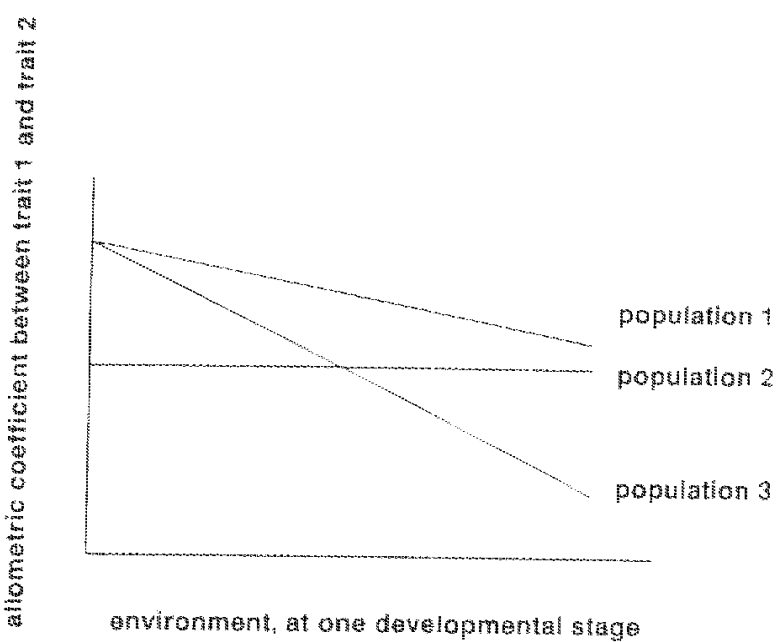

Fig. 6. Combing allomety and pastich: apresentation of the eftect of changhy the envinmen 10.9 . decteasmg tood supply on the relationshp uetween mains le.g. body size and reproductive output, measured at angle develop mental stage. The alometric cotfichent is unaflected by the onvironment tor popuation 2 , but changes is plastel in the other two populations.

is going to be different in different envionments, as elegantly demonstrated by Neytakn and Hart (1993).

\section{Ontogeny and Pasticity}

Peaction noms are uswally studied at the adult stage, mostly for simplicify folowing several genotypes in diferent enuronments throughout their growth can be cumbersonel. Analogously, ontogenies are often characterized for organisms raised in one-wasualy standard. ized-envionment. But, like any other aspect of the phenotype, reaction norms onginate through a developmental process, and should therefore be studied from a developmental perspectve in order to be properly understood Steams, 1982, 1983). Some researchers have recently addressed the plasticity of ontogenetic trajectories in a few model systems Mathis, 1990 ; Diggle, 1991a, b, 1993, 1994; Jones, 1992, 1993. 1995; Pigluce and Schlichting, 1995 ; Piglucel et al., 1996). Jones (1995), utilzing detaled ontogenetic analysis, demonstrated that less-lobed, more juvenle looking shade leaves of Cucurbita arose through plastic responses wher than as a prolongation of the juenile phase.

Such anaves directy provide insights into how the parameters affecting growh lonset, of tset, and rate of developmental events) are atered by changes in enviroment $(\mathrm{Fig} .7)$. Some characters may have a very stable oniogeny across a wide array of conditions. While others can be extremely sensitve to changes in the environment. A knowedge of these differences would help our understanding of the cevelopmental 


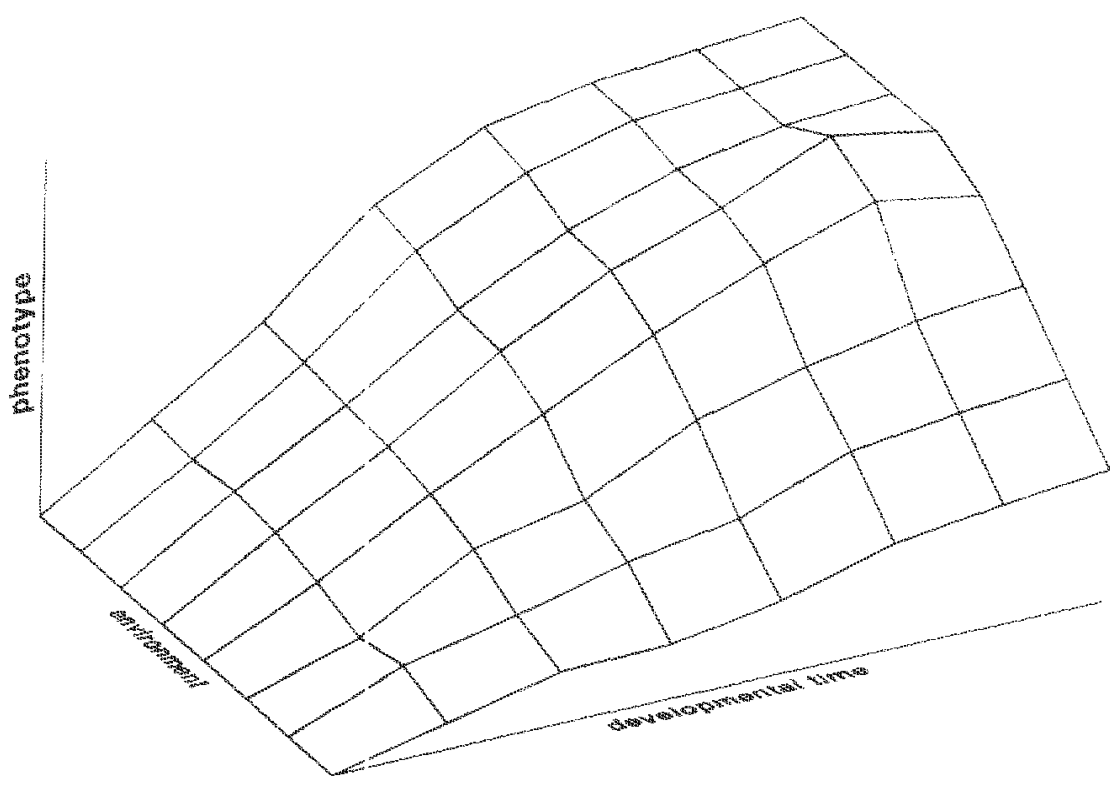

Fig. 7. Combining ontogeny and plastciry the lines along the development time axin represent the ontogeneto trajectories for a single trait (e.g. body mass) measured across several diferent environments (e.g. dfferent temperatures. The trait attens low valus in some environmenss and higher values in ohers.

mechanism iselt, and of how some parts of it evolved to either be resistant or to respond faxibly o hetero. genous conditions.

\section{The Threeway Integration: Complexiny in the Sudy of phenorypes}

We have presented the progression from isolated views of phenotyes based on alometry, ontogeny and plasticity, to the possible two-way interactions between them. The logical extension of this progression leads to the complete integration of the three aspecte of phenotypes so far discussed Pigluccl and Schichting. 1995; Piglucel at al. 1996). Ontogeny can be measured for mutivanate traits and across environments: alometric coefficients can be calculated under dfferent conditions and throughout the ontogany; and reaction noms of character correlations can be plottec at different times during the development (Fig. 8 ).

Clearly, both the envirommental and the phenotypic axes are themseves mutidmensional in the real world. and we recognize that it is impossible to cature the whole of organismal complexiry in a single graph. The pont, however, is not just to present a diferent or more complete way to graphicaly visumize the phenotype. The important message is that the concept of the developmental reaction nom as characterized by the three-way interaction can provide us with new insights into how phenotypes are generated and evolve.

This integrated view explictly addresses the potential for: It the enviroment to modify developmental tajectories: (2) different developmental stages to be more plastic than others: and 3 the changes of cor related character complexes to be substantialy more in. tricate than single traits considered in isolation. Thus, we suggest an integrated view of the phenotype as the genotype-specific responge of ontogenetic trajectories to environments. We consider the developmental reaction nom as the object of selecton. leading to the con. clusion that selection can differentialy affect the phenotype depending on its time and place of acton, a resut that, while obvious in this context, is virualy ig. nored in current models of phenotypic evolution.

Admitedy, few researchers will find it necessay or even possible to address all these facets within a single study. However, what we are advocating is a change in perspective, leading to the contmuous awareness that bll those pieces are there even if we ignore some of them for the sake of convenience. Utimately, our abilty to understand the intricacies of phenotypic evolution will depand on our capacity to inegrate its separate components. After all, even though we are forced to focus on perticular aspects of the organism at any given time, natural selection continues to operate on the complex whole.

\section{Evolution of Developmental Reaction Norms}

In our view, the evolution of developmental reaction 


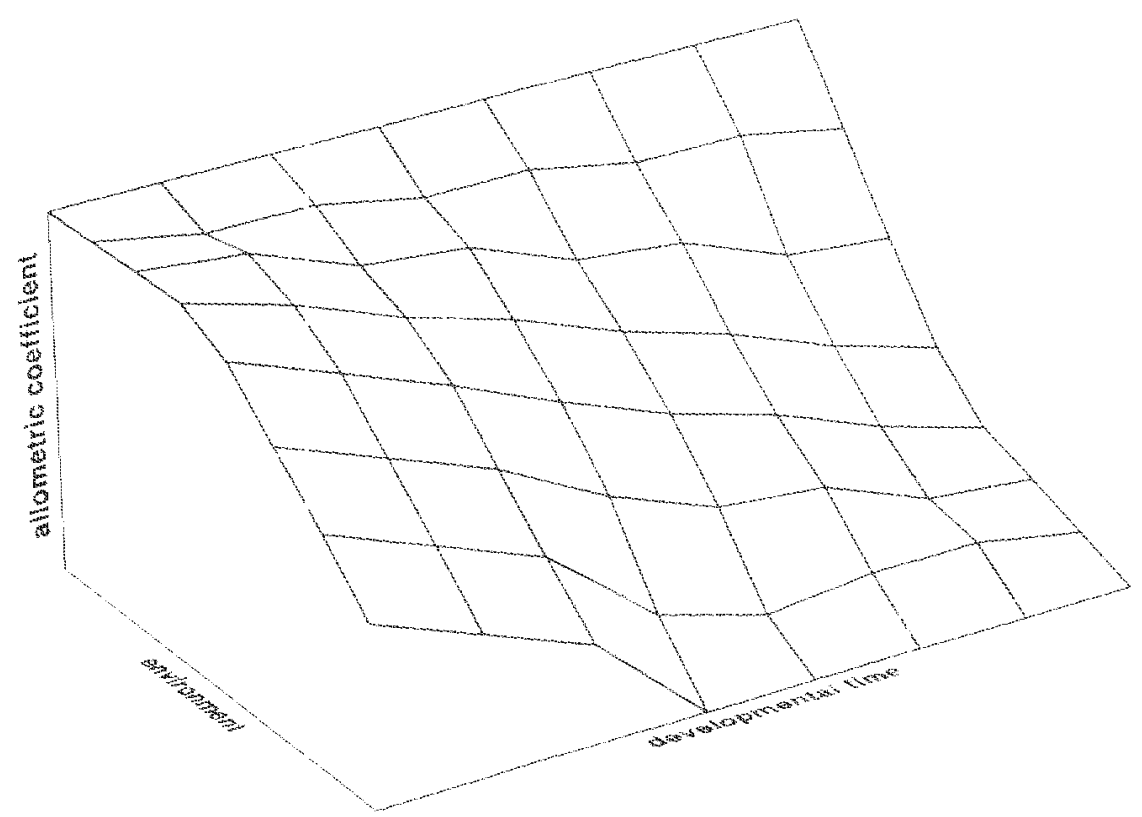

mental reation nom Combing alometry, ontogeny and plastioty This is a dagram-

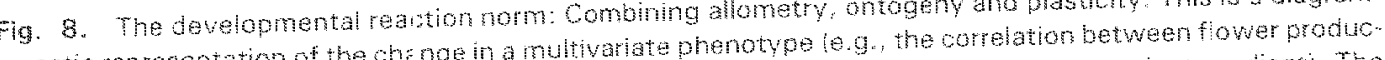

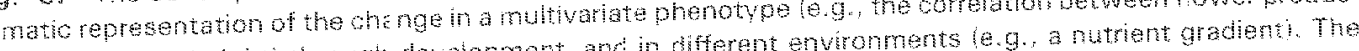

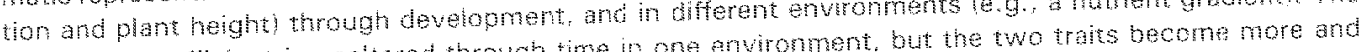

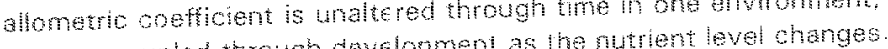

more coupled through develonment os the

noms vroceds by means of alterations of the epigenetic system. In this section wa discuss the mechanistic bases of epigenetic systems, and utmately of phenotypes. We then consider the means by which de. veloomental reaction moms can be altered, and finally we discuss the evolutionary outcomes of the selective forces and the constrants acting on shenotyes.

Evolution can be examined by analying changes in the genetic composition of populations and species. The raw material for such changes is provided by a panoply of "mutational events: soint mutations. chromosmal rearangements, gune conversion. moblization of transposons and chenges in methylation pattens (among others). Each of these can modfy the environment specificty of the epigenetic system to produce changes in the developmental reacton nom.

Aternatively, we can atudy the phenotypic effects accrung from these warious causes: the commonly inwoked heterochrony changes in timirig or rate of developmental eventsi, canalization reduction of develop mental instabiltyl or less well understood phenomena such as modifcations of cell movements or of the plane of cell division, alterations in tissue induction and difer. entiation patems, and structural changes n receptors or in allosteric enzymes Monteiro e: al. 1994; Nehrs et al. 1994: Schmidt. 1994: Wiliams at at. 1994 Wolpert, 1994; Kondo and Asai, 19951.

\section{The Eplgenetic System}

Since the discovery that DNA is the "infornation" mole. cule that organzes the development and function of living organisms, evolutionary biology has slowly becone trapped in the metaphor of the "blue print". DNA is often regaried as a manual of instructions that details every aspect of biologicalorganization. In light of what we now know about gene expression, this view should clearly be revised.

In order to begin to understand epigenesis, we must first extact its general attributes. We propose that there are fundamentaly four: $1 /$ the action of individual genes during development is local, 2 lgenes interact di. rectly only with small numbers of other genes. 3 there are mutuple levels of regulatory control, and 4 the phenotypic outcomes are not predictable mom a detaled knowledge of gene action if.e. there are emergent properties).

The concept of a blueprint is thet of a plan to specty or anticipate every possible situation and the response most appropriate to it. However. no molecule can store a much infomation as needed for the detalied descrip. tion of the phenotype. moluding al the biochemical pathways and developmental intersctons, and the reac. tions of all these to the emviromment, A modular organiration on the other hend. Is constructed so as to partition the decisionmaking process at several partialy independent levels. increasing the overall fexibilty of 
the system. Theretore, what DNA does is to generate products from groups of genes that are characterized by localized action, without any drect reference to the overal scheme. The outputs of these numerous local gene actions are controled by regulatory elements that direct development along altemative pothways depending upon intemal or extemal "environmental" condi. tions. Selection works on these iocal gene efects based on their contributions to the final "outpur" of the program.

The geneticepigenetic program of develomen falls into the category of the undecidable: no matrematica treatment wil be able to pradic exacty what an organism will look like (sea, for example, our incomplete understanding of how the phage z works, even though the complere sequence of its genome ras been avalable formany years: Ptashne, 1992 ). The combina. tion of local action and loose connectivity of the genetic modules leads to what are then percoved as "emergent properties". The dynamics of genetic algorthms and neural networks are "emergent", in the sense that they are not specified in the lnes that make up the program, nor were they necessarly intonded by the programmer le.g., eans, 1994).

The importance of the environmental component can be appreciated if we consider a particulary popular version of genetic algorithms, a class of progrms that "leam" to play games (e.g. chass) more and more efficiently through a series of trial games with op. ponents of varying skil. The algonthms evolve niffer. ont ways, depending on which "enviromments" the pro. gram has been exposed to. Yet, the longterm sutcome is remarkably simlar: programs capable of piaymg and wirning against highly sophisticated opponents. In a biological context, these disparate evolutionary trajec. tories can be paralleled with the evolution of the same reaction nom by different genetic-epigenetic systems "genetic redundancy", "genetic piracy": see below).

Wincut et al. $1198 \mathrm{~s}$ applied concepts of localized gene action and complexity theory to biolog cal processes when they investigated a celular automata model of development and phylogeny. They spectied a series of simple genetic mies according to which their "wild type" was constructed, and then mutatod some of these rules to examine the effects. There was no way to tell a pror what a specific change in the rules was going to do to the relatively simple morohslogy of the wo dimensional automaton! Mutations causing change in rate of gene action did not cause morphological heterochrones, white some apparanty heterochronic atterations in the adut phenotype did not arise from heterochrony at the gene level.

A vew of avolution by change of local rules or of the control mechanisms that supervise the interaction among genetic subroutines leats to explanaions of several evolutionary phenomena affecting the esgenet. ic system. The possbility of compting some zarts of the network of gene interactions for a new and possibly unrelated task is what foth called genetic piracy' Roth, 1988: Carroll. 19941. Foth cites as an example the evolution of convergent developmental pathways leading to a single control of the formation of hind and lorelimbs in vertebrates, once completely distnct mor. phogenetic systems. A somewhat similar phenomenon is genetic redundancy, in which the same phenotype is produced by genetically distinct backgrounds Golds. tein and Holsinger, 1992; Dove. 1993; Thomas. 1993).

\section{Generic and Epigenetic Modifications of opN}

Because the developmental reaction nom integrates a complex view of genotype, development, and environment, we view the importance of "mutational" guents that generate genetic variation in tems of their effects on the epigenetic system. Therefore, an important issue is what kinds of genetic changes can affect tha epigenetic system, and hence the developmental reac. vion nom? Two fundamental phenomene have been proposed as instrumental in changing the course of development: heterochrony, or the change in timing of gene action/developmental events; and heterotopy, the change in the place of gene actionidevelopmental events.

Heterochromy has always been considered a central process in the ovolutionary change of developmenal partems. The word heterochrony was introduced by Haeckel 11875 within the framework of his recapitula. tion theory, but the modern sense of the word comes from de Beer (1940). An histoncal as well as technical review of these concepta is to be found in Gould (1977), and updated in Mckimey and McNamara (1991) Gould (1977) and Aberoh and coworkers (Alberch et al., 1979; Abarch, 1982 ) simplifed de Beer's teminology, proposing a model for the understanding of heterochronic phenomena which -at least potentially -is amenoble to a link with genetics ifor example see Slatkin, 1987). However, the relationship between phenotypic heterochrony and changes in timing at the leval of the gene has rarely been shown to be din rect Ratf and Wray, 1989; Wray and Faff, 1991; Bassiri et al. 1992: Convay and Poethig, 1993; Ambros and Moss, 1994: Collazo, 19941. In some cases, heterochronic changes have been shown to be owviron. mentaly triggered with macroevolutionary implications for phenotypic plasticity such as the studies of diat-induced changes in jaw momhology in cichids (Meyer, 1987) and paedomorphosis in ambytomid salamanders 19.9. Semlitson et al., 1990).

Heterotopic phenomena are less commonly reported and less well understood than heterochronic ones. This difference might be due to the fact that the detection of heterotopy reculres detaled knowledge of gene action and of its mapping onto phenotypic effects. information that is seldom avalable to the evolutionary blolo- 
gist isee e.9. Simpson et al, 1986; Fanget al, 1991 ; Duboule 1904 . Wray and McClay (1939) reported on the potential impotance of changes $n$ the place of gene action toward explaning the adaptive radiation of echinoids in the Early Paleozoic. Analyses of pattems of time and ste of gene expression for three protens in seven echincid species ffor which a relable phylogeny was avallable reveated heterochronic and heterotopic changes for all three protems.

Many of the mechanisms for modifying epigenetic systems are being uncovered in the intensive research currently underway on the function and evolution of homeotic genes for recent reviews be Manak and Scott, 1994; Meverowitz, 1994; Patel, 1994; Carrol. 1995). Wok with anmal systems mont notably mice. Drosophila and the nematode Caenomabdits has revealed major areas of homology among the homeobox genes Manak and Scott, 1994; Salsar and Kenyon, 1994: Warren et al. 1994; Sordino et al. 19951. Work with plants such as Arabidopsis has in dicated the presence of homeotic genes as well ICrone and Lord, 1994: Meverowitz, 1994; Ray et al., 1994: in addition, itreration of pattern formation INiehrs et al. 1994: Rverapomar et al. 1995) and modularity/segmentation IAkam et al., 1994a; Patel, 1994), changes in signal transduction (Brown and Hartley, 1994 ; Patel, 1994 , change of function (rake. 19921, and changes in patterns of cell movement Salser and Kenyon, 1994 ) have al been identified.

\section{The Evolutionary Ottcome: Selection and Con} straint

The evolution of the developmental reaction nom is ultimately a matte of balance betwe nn the selactive forces acting on the epigenetic system, and the variabilty lor lack thareof of the genetic machinery driving the epigenetic aystem itself. The limits and preferential routes that are supermposed on selection are collectively known as "constrants". We wish to discuss this concept in some detall in order to acheve a more complete picture of how developmental reaction noms chenge through evolutionary time.

Biologists have a bewidering salection of "con" strants" to choose from: genstic, phylogenetic, mechanical functonal, developmental, selective. ecological, to mention but a few. The literature-and the spirited controversy-about constraints is so vast that any attempt to synthesize the matter is doomed to be both incomplete and a very delicate operation lsee e.g. Antonovics and van Tienderen, 1991: Perrin and Travis, 1992; van Tienderen and Antonovics, 19941. However, we will attempt it anyway.

Athough several previous overviews of the concept of constrant have identified both genetio and develop. mental constrants as distnct from selection Maynard Smith at al., 1985: Soharloo, 1988: Wagner, 1988: Arnold, 1992: Schwenk, 1995), here we identify only wo comprehensive categotes of evolutionary forces: selective pressures (positive or negative forces) and geneticlepigenesic constraints (negative forces/ IFigure 9). Evolutionary change lor stasis results from the outcome of the interaction among the possibie components of these two forces. Note that smetimes selection and genetic constrants wan act in the same di. rection: for bxample, stabiling selection tends to decrease genetic variation, which in turn will keep the population im the current area of the phenotypic space.

We can use the developmental reaction norm perspective to visualize the process by which selection and constrant define phenotypic space. We have devis.

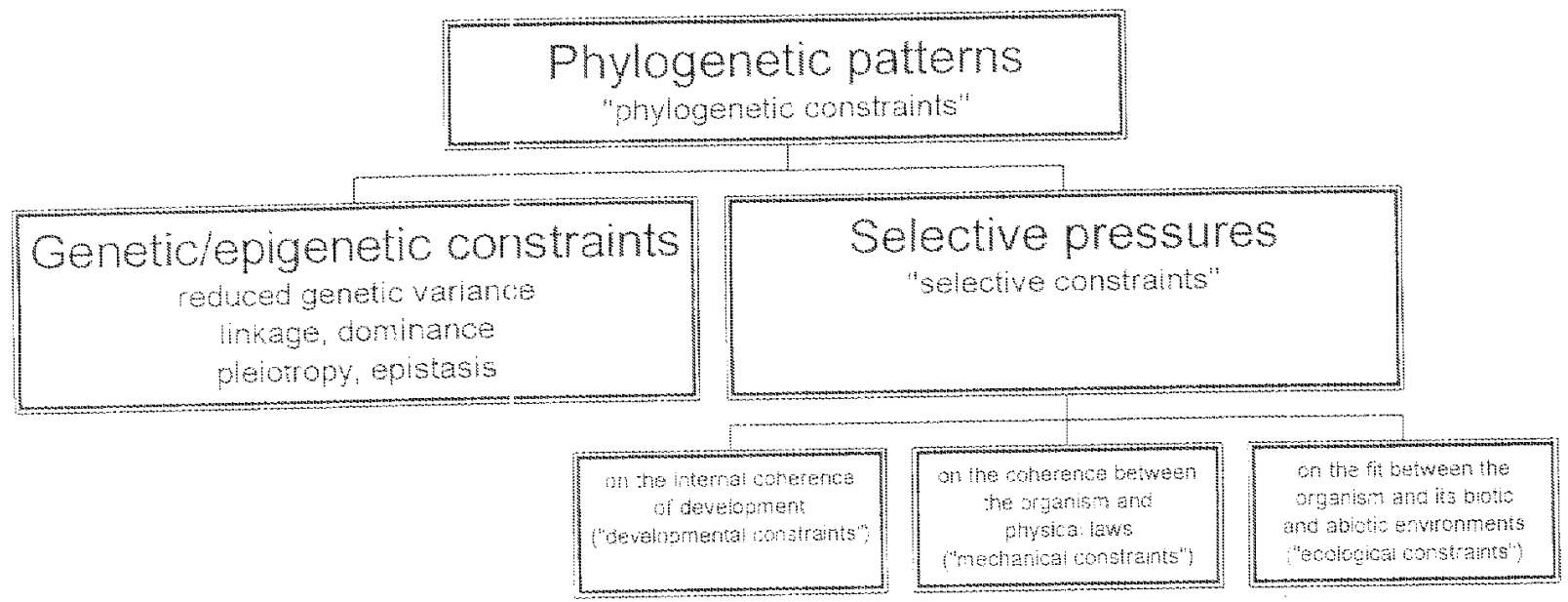

Fin. 9. Genetichpigenetic cor strants and selectve pressures. These two categores of evolutionary torcas

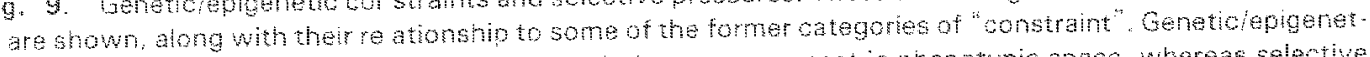
ic constrantic are regative forces, Imiting evolutonary movement in phenotypic spece, whereas selective presures mav be positive drectionaldismptwe selection or negative stabiling selecton forees. 
ed a scenario in Fioure 10 fror the hypothetical determination of digt mumber moving from the level of the gene through the epigenetic process to tre phenotypic state. The character has a genetic component and if there is only a single alela for a gene, ia genetic con straint exists. In out example there bre mutiple genes with mutiple alles contributing to the expression of a continuous character, cell number. The epigenetic rules provide for a symmetrical biturcation of sels when the cell number exceeds 300 . converting the continuous cell number distribution into a discrete pattem of 1.2 , $4,8 \ldots$ digis. In this example, we have a so set limits to cell number through natural selection - combinations of alleles that result in $<125$ or $>1000$ calls are lethal due to distuption of the developmental system, restricting digit production to through $a$

Athough an analysis based on the fitness function suggests that 2, 3 or 4 digits would be equaly fit, the epigenetic rule resuts in a petten of phenotypic expression li.e., 2 of 4 , but not 3 digits that would be recognized as a 'developmental constrant. By examiming the developmental reaction nom, we can see that this patten results from the epigenetic we of bifurcation of the cell mass that we specified an eplgenetic constraint Thus expression of diferent sets of alleles at the lower level li.e. cell number is controled in tum by
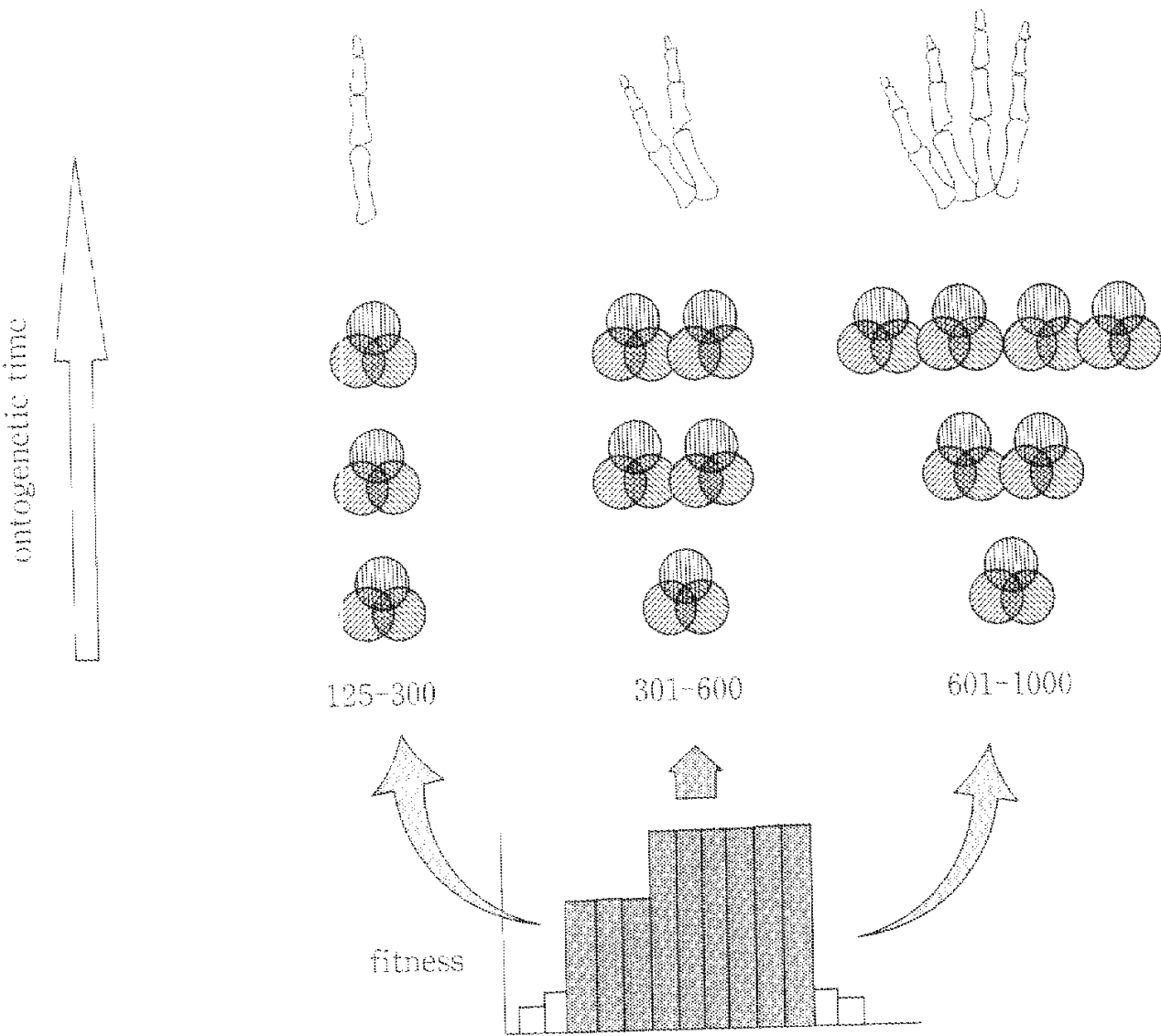

n. cels $\$$ digirs

wew of the relationsho betwegngenetrepigeneto constain and

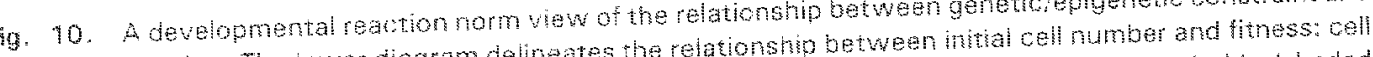

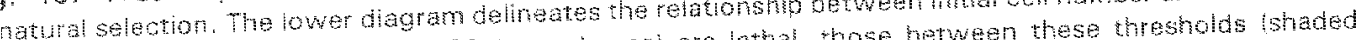

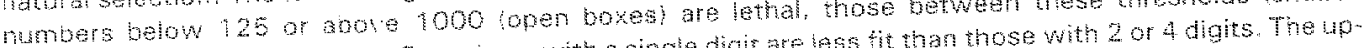

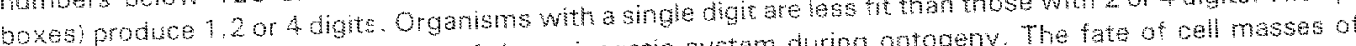

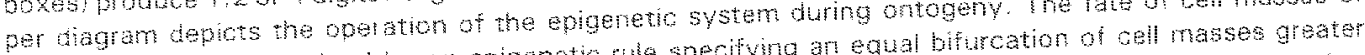

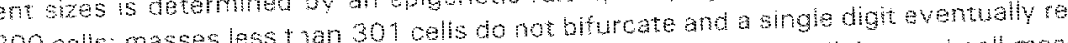

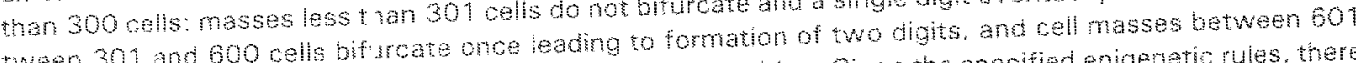
and 600 cels bif aroaro once and 1000 cells bifurcate sesond the whe

is no way to produce the digts, even though such an organism wo 
the action of other genes at a higher level ibfurcation rule), resulting in an example of epistasis. However, it. becomes dear that if we shift our forus to that higher level of the hierarchy, the observed pattem of 1,2 or 4 digits results from a genetic constlant: there is no allelic variation at the gene locidetemining the bifurcation rule. To get three toes, wa could envision a rule thar might allow a thfurcation, or one that results in an unequal division of the cell mass.

The process of bulling and breaking constraints through evolutionary time results from the continuous interplay between the expressed phanotypes and the agents of netural selection, and the subsequent feedback onto the developmental syster. The phenotypes we observe are a snaphot depioting the current devel. opmental reaction norm. As new alleles arise, their pleiotropic and epistetic effects mist be integrated wh the existing genetic architectire-selection will favor those with higher fitness and trese may become estabished in the population. However, because there nay be a number of possible alless any oven locus that could be successfuly integrated, the actual identity of the new allele for the partcular locus will help determine the success or tailure of ater opportunities for "tinkering". This is the historical contingency larising from the random appearance of new alleles that has been referred to as "phylogenetic constraint". Thus access to some portions of phenotypic space will be prohbied sometimes directy by selection, sometimes by geneticlepigenetic constrant, and often by the constraints resuting from pravious episodes of selection, drif or chance mutational events.

From the pont of vew of this paper, the important aspect to consider is that because phenovpic evolu. tion resuts from modifications of he developmentai reaction nom of the genetic-epigenetic system, then selection and constraints in particular environments can have ramifications for the entre reaction nom, and not ony the phenotype produced in the locus environment contra Via, 1987, 19941 . This implies that in order to produce a realistic represer tation of an evolutionary trajectory, we need an understanding of the range and frequency of acual environments in which evolution ocours, and a description of the envirommentspecific selective pressures and constraints.

\section{Conclusions}

1. The developmental nom of reaction is the object of selection. We see the phenotype of an orgonism as charactarized by the potentality of its genotype to ex. press a seres of developmental traj sctories, depending on the particular set of anvironmental conditions to which the individual is exposed. This view stems from three basic considerations. First, the common locus on acult stages may lead to a restricted understanding of evolutionary potentials. The origin of the observed differences in adult phenotypes can ony be understood by tracing their ontogenetic trajectories. In some cases, simianties in adut phenotypes may not be due to the same developmental pethways (Lones, 1993; Pigluoci and sohlichting. 1995: Pigluce et al. 1996. From what we know about gene expression and organ zation, major phenotypic effects cam be obtained by attering either the time of the place of gene action. Therefore, heterochrony and haterotopy of gene action represent major ways to alter ontogenetic trajectories.

Second, an organism cannot be considered independently from its emvironment. To discuss phenotypes without the context of particular and ecologicaly rele vant environmentsi neglects a orucial aspect of phenotypic complexity. Third, organisms are hamonious ensembles of trats, and character correlations and in tegration must play a fundamental role in our theories of how selection and constraints shape phenotypic evolution.

We explicitly integrate these thee components of the phenotype in our concept of the developmental reaction nom. Evolution procesds from a dalectical in. teraction between organisms and environments through ontogen.

2. The innate complexity of genetic systems necessarly leads to emergent properties, usually en compassed by the term "epigenesis". We consider misleading the common metaphor of genes encoding the "blueprint" for the phenotype. More realistically, genes represent a series of subroutines that interact with each other, intiating and localy controling the events that unfold during ontogeny, in principle. knowledge of the mechanistic details of what each subroutine does and how it interacts with others, does not allow prediction of what the final phenotype will be. As a consequence, the phenotypic effects of altering the rules (i.e. mutation are also unpredictable. Converse. $y$, it is aiso not possible to pradict the genetic basis of a particular phenotypic change.

Epigenesis then, is the deteministic yet "undecidable", series of ontogenetic events resulting from the interaction of numerous local genetic systems las opposed to a global central controll.

3. Both the control of the development of complex phenotypes and the capability of these to respond to environmental variability intemal or extemal requires a system of balanced regulatory interactions. Both surveys of current knowledge of the molecular mechan. isms of gene regulation (Schlichting and Piglucot, 1995a: Piglucci, 1996, and models of gene networks based on complexity theory point to the occurrence and advantages of intermediate and localized levels of regulation (Bak and Chen, 1991 ). Systems that are 
very tighty regulated are prone to instablity isomalled "complexity catastrophes". On the other hand, classical Fisherian models of independent genes addively acting on the phenotype lack the connectivity that is nec essary to readily move within the adaptve landscape. and show the tendency of setting on local rather the global optima.

We have arrved at this view of the phenotype by combining our different vantage ponts of evolutionary morphology, the evolution of development, and ecologi. cal genetics. These disparate viewponts have made ut receptive to the argument that development was lett out of the grand synthesis of the ' 30 and' 40 s, and cognizant of the imporance of a view of shenotypes from a reaction nom perspective. Thus, the move toward combining ontogeny and reaction noms was a natural progression. The difficultes inherent in combin. ing all aspects in an experimental program are obvious. However, even if all components are not explichly ex. amined, we believe that it is just as important to openly mamtain an awareness of the potential conributions of the environment, the interactions among trits, and the possible roles of other ontogenetic stages, when assessing phenotypic expression and wolution.

Acknowedgements We thank the many people who have given their time to reading drafts of this time of for extensive discussions of various pointa: Jennifer Butar. Phil dilono, Charles Henry, Kent Holsinger, Rick Milat, Coutney Muren. Sean Rice, and Cunter Wagner. They do not necsssarily agree with all we have written here in fact, the authors have been hard-pressed to reach consensus on some of hese issues? CDs wishes to single out the intestinaly-challenged anonymous reviever who encouraged us to "oncentrate on dongless better." MP was stipoorted by NSF oissartation improvement grant DEB91-22762, COS by USF DEBS220593 , and CSJ by NSF DEe94-08208.

\section{References}

Akam, M. Averhot M. Castelli-Gair J. Dawes. A. Falcisni, F and Ferren, 0 . 1994a. The avolung roles of Hox genes in arthropods. Development, Supplement: $209-215$.

Holland, P. ingham, $P$ and Wray, G, $1994 \mathrm{~b}$. The

Evoluton of Developmental Mechanisms. The Company of Biologists, Cambridge.

Aberh. P. 1982. Developmental constraint in evolutionary processes. In: Bonner, J.T. led. Evolution and develop. ment, $313-332$. Spminger-Verlag. New York

ment. Gould sj oser. G. and wake, C. 1979. Size and shape in ontogeny and phylogeny. Paleobioboy 5 : $296-317$

Ambros, $v$ and Moss. E. . 1994 . Heterochronic genes and the temporal control of $C$ elegans devolopment. Trends in Genetics $10: 123-127$

Andesson, S., and Shaw, R.G. 1994 . Phenotypie plasticity in Coms tectorm Asteracesel: genetic correlatons across inht regimens. Heredity, $72: 113-125$
Antonovics, J, and van Tenderen, P.H. 1991. Ontoecogenophioconstrams? The chaos of conctraint teminology. Trends in Ecology and Evolution 6: 166-168.

Amold. S.1992. Constraints on phenotypid avolution. Am. Nat. 140, Supdement: $\$ 85.5107$.

Arthur, W. 1988. A Theory of the Evolution of Development. John Wiey \& Sons, New York.

Atchey W. 1984. Ontogeny, tming of development, and genetic variance-covariance structure. Am. Nat 123 : $519 \ldots$ 540 .

and Hal, B.K. 1991. A model for development and evolution of complex morphological structures. Bio. Rev. 86: $101-157$.

Bains, $\$ 1994$. Even a robot cricket always gets her mate. Soence 266: 1809.

Bak, P., and Chen. K. 1991 . Selforganized criticalty. Sol. Amer, January: $45-53$.

Barton, N.H. and Tusli, M. 1989. Evolutionary quantitative genetios: how hitle do we know? Ann. Rev. Genet. 23: $337-370$

Basciri A. Irish E. E, and Poethig, R. S. 1992. Heterochronic effects of Teopod 2 on the growh and photosensitivity of the Maze shoot. Plant Cell 4: $497-504$.

Bonser, S. . and Aarssen, L.W. 1994. Plastic alomety in young sugar maple Acer saccharuml adaptwe responses to light avallabilty. Am. A. Bot. 81: $400-400$.

Gradshaw A.D. 1966 . Evolutionary significance or phenotyp ic plasticity in plants. Adv. Genet. 13: 1 16-155.

Grown. N.H. and Hartey, D.A. 1994. Exploning signaling pathways Nature $370: 414415$

Carroll S. B. 1994. Devalopmental regulatom mechanisms in the evolution of insect diversity. Develonment, Supplement: 217.223

217.223. 1995 . Homeotic genes and the evolution of arthropods and chordates. Nature $376: 479-485$.

charlesworh, B. 1990. Optimization models, quantitative genetics, and mutation. Evolution 44: $520-538$.

Cheplick, G.P. 1995. Lfe history trade off in Amphibromes scabrvavis Poacaeal: albcation to dond growth, storage, and delstogamous reproduction. Am. J. Bot. 82: $621-629$

Cheverud, JM. 1982. Relationships among ontogenetic static, and evolutionay alometry, Am. J. Phys. Anthropol. 59: $139 \cdot 149$

Cock. A.G. 1960. Genetical aspects of metrical arowth and form in anmals. Guar. Rev, Biol, 41: $131-190$.

Colazo, A. 1994. Molecular heterochrony in the pattern of fibronectin expression durng gastulation in amphibians. Evolution 48: $2037-2045$.

Conway, L.J., and Poethig. F.S. 1993 . Hetrochrony in plant develoment. Dev. Biol. 4: 65-72.

Cowley, D.E and Atchley, W.A. 1992. Ouantitatve genetic models for development, epigenetic selection and phenotypic evoution. Evolution 46: $495-518$.

Creighron, G.K. and Strauss. R.E. 1986 . Comparative pat. rems of growth and develoment in cricetine rodents and the evolution of ontogeny. Evolution 40: $94-106$.

Crone, $W$ and Lord. E.M. 1994 . Foralorgen mitation and de velopment in a wild-ype Arabdophs thaliana Brassicacede and in the organ identily mutants apetala $2-$ ? and agomous 1. Con. J. Bot. 72: 384-401.

de Beer. GR. 1940. Embryos and Ancestors. Carendon 
Press, Oxford.

de Jong, G. 1995. Phenotyplo plasticity as a product of seiec tion in a varioble environment. Am. Nat. 145:493-512.

Diggle. P.K. 199le. Lable sex exprassion in andro monochous solanm hrtum floral moro logenesis and sex determination. Am. J. Bot. $78: 377-396$

- 19910. Lable sex expression in andromonoecious Solanum hirtm: sources of variaton in mature floral strucure. Can. J. Bot, $69: 2033-2043$.

-1993. Developmental plasticity genetic variation. and the evolution of andromonoey in Solanum hitum (Solanaceae). Am. J. Bot. 80: $967-973$

1994 The expression of andromonosey in Solanum hrtum (Solanacadel: phenotypic plasticty and

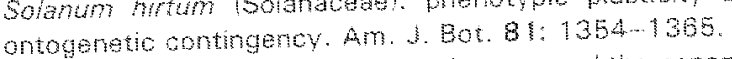

Dove W.F. 1993. The gene, the polvgens, and the genome Genetics, 134: 999-1002.

Dragavtsev, V.A., and N.V. Utemisheva, N.V. 1975. Ontoge netic sriabily of statistical ganevic parametars in plant populations. I. Theory of the problem Senetka 11: 128 140.

Duboule, 0. 1994. Temporal colinearity and the phylypic progresion a hasis for the stability of a vertebrats Bauplan and the evolution of mophologies through heterochrony. Development, supplement: $135-142$.

Fand $X$. Wu, C. and Brennan. W.S. 1931 . Complexisy in evolved regulator vanation for alco zol dehydrogenese genes in Hawailan Orosophla. J. Mol. Evol. 32: $220-226$. genes in Hawalan 1940 . The Materal gasis of Evolution. Yale Unversity Press, New Haven.

Goldstan D B. and Holsinger. K.E. $19 \$ 2$. Mantenance of polycenic variation in spatialy structured populations-.poygentic for locating and genetio redundanoy. Evolution 46 $412-429$

Gottleb. G. 1992. Individual Development and Evolution: the Genesis of Novel Behavior. Oxford Unversity Press, New York.

Goud, S.\$. 1968. Alometry and size in ontogeny and phylogeny. Biol. Rev. 41:587-640.

Gould S. To7\%. Ontogeny and Phylogeny. Belkndp Prese. Cambridue

Gupta, A.P. and Lewontin, F.C. 1982. A study of reartion Gupta. A. ., and bewonth hatural populations of Drosolha pseudoobscum. Evolution 36: 934-948.

Haekel E 1875. Die Gastrasa und die Efurchung der There. Jena 2. Naturwiss. 9: $402-505$.

Hake, 5.1902 . Unaveling the knots in plant development. Trends in Genetics 8: 109-114.

Hakkanen, H. and Korpimak, E. 1985. Contrasting phenotypic correlatione in food provision of nate Tengman's ovils Aegolus funereus in a temporaly heverogeneos anviron. ment. Evol. Ecol a: $30-37$

Hall B.K. 1992 . Evoluronary Developmental Bology. Chapman and rall.

Houle. D. 1991. Genetic covarince of titness correlates: what genetic corretetions are made o and why it matters. Evolution 45: $630-648$

Huxley, J.S. 1932 Problems of Relative Growth. Macveach, London.

Johamsen, W. 1911 . The genocype cunception of heredity. Ami Nat. $45: 129-159$

Joloceur, P. 1989. A simplified model for bvariate complex alometry. J. Theor. Biol 140:41-49.

Jones. $\mathrm{S}, 1992$. Comparatve ontogeny of a wid cucurbie and its derved outvar. Evolution 46: $1827-1847$.

- 1993 . Heterohrony and heteroblastic leat development in two subspecies of Cucurbita argrosperma lCucurbitaceael. Am, J. Bot. $80: 778-795$.

1995. Does shade prolong juenile development? A monhological analysis of leat shape changes in Cucurbta aroyrospema absp. soronia (Cucurbitaceae). Am. J. Bot. 82: $346-359$

Kelogg. E.A. 1990. Ontogenetic studies of florets in poa Gramineael alometry and heterochrony. Evolution 44 : $1978-1989$

Kingenberg. C.P. and Spence. J.R. 1993. Heterochrony and allometry lessons from the water strider genus Limnoporus. Evoluton 47 : $1834-1853$.

hopors. Evimmermann, M. 1992. Static, ontogenetic, and evoutionary allometry: a mutvariste comparison in nine specles of water striders. Am. Nat. 140 : $601-620$.

Kondo, S. and Asai, F. 1995. A reaction diffusion wave on the skin of the marne angentish pomacanthus. Nature 376 : $765-768$

Lande, R. 1979 . Muntitatwe genetic analysis of multwariate sulution, appled to bram, body size allometry. Evolution 33: $402-416$.

Lehowicz. M.J., and Blas P.A. 1988 . Assessing the con tributions of multiple interacting trats $t o$ plant reproductive success enviromental dependence. J. Evol Biol, 1: 255 273.

Manak, I.R. and Scot, MP. 1994 . A class act: consevva tion of homeodomain protein functons. Development Supplement: $61-71$

Mathies 0. 1990. Pasticity of reproductive components at differst stages of development in the anmuat plant rhaspl arvense L. Decologia 83: $105-116$.

Vavard Smih, J., Buran, R., Kautman, S. Aberch, P. Campoel J., Goodwn, B. Lande, R. Raup, D. and wopert 1. 1985 . Developmental onstrants and evolu. ton. Quart. Rev. Bid. 60: 265-287.

Mckiney M.L and Mokamara, K.3. 1991. Heterochrony the Evolution of Ontogeny. Plenum Press New York.

Mever A. 1987 . Phenotyple plasticly and heterochrom in

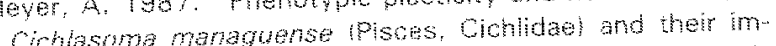
fications for speclation in Cichid fishes. Fvolution 41 : plications for

Meyerowitz EM 1994, Fower cevelopment and evolution: Meyew answers and new guestions. Froc. Natl. Acad Sci. USA $91: 5735-5737$

USA 91: W Wim. A.A. and schemeke, O.W. 1994. The effects of density and satial distribution on selection for

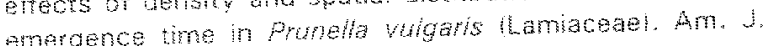
Eot. $81: 1-6$.

Monteiro A.F Brakefeld, P.M. and French, V. 1994. The evolumbnary genetios and developmental besis of wing pat tem varation in the butterly Bicyclus anynana. Evoluton 48: $1147-1157$.

Nevilh A.A, and Hart. O.L. 1993. Genetic control of the rate of embryonic development: selecton for faster develop. ven at elevated temperatures. Evolution $47: 1625 \cdots 1631$ Nehrs, C. Stambeser. H. and hobertis, EMD. 1994. Masodemal pateming by gradent of the vertebrate homeobox gene goosecold scince $263: 817-820$. 
Nihout H.F., Wray, G,A. Kemen, C, and Teragawa, C.K. 1986. Ontogen phylogen and evolutor of fom: an aloorthmic approach. Syst. 200 , 35: 445-4in

Patel, NH. 1994. Develommental avoluton: insights from stidies of insect segmentation. Science 266: $581-590$.

Perrin, N. and Travis, 1902 . On the use of constramts in evolitionary biogy and some alergic reachons to them. Funct. Ecol $6: 30: 363$

Piglicol, M. 1996. How organgms respond to enviromen tal change: from phenotyes to molecules (and wo versa) a thange: from phenotypes to molecules land

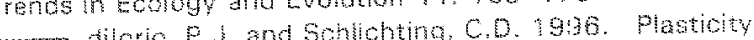
of ontogenatic trabctores, phenological and reproductive

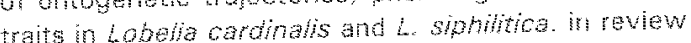

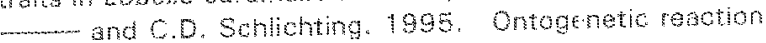
norms in tobela siphilica (Lobelaceas) respones to shadng. Ecology $76: 2134-2144$.

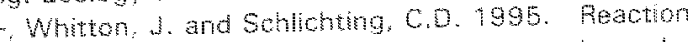
nom of Arabropsis I. Pacticiv of charecters and comelo. thons across water nutrent and ligh gradients, J. Evol Bot. 8: $421-438$

platenkamp. G.A.1. and Shaw, R.G. 1992. Environmental and genetic constraints on adaptve powulation diferenta.

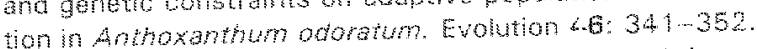

1992. A Genetic Switch Phage Eamband Hicher organisms. 2nd ad. Blackwol Schentile. Cambridue Padinsky, 1. 1984 . Ontogeny and phylogeny in horse skull evolution. Evolution $38: 1-15$.

Faff. F.A., and Wray, G.A. 1989 . Hetarochrony: develop mental mechansms and evolutionary resulk: J, Evol. Biol. 2: $409-434$.

Wray G.A. and Hony, J.J. 1991 . Implications of radical evolutomary changes in enty development for con capts of develomental constrant. In: Varren, L. and Koprowski, H. (ed.) New Perspectives on Evolution 189 207. Mlley-liss. New Yotk.

Pay A. Pobinson-Beers. K., Foy, S., gaker, S.C. Lang. L. O.

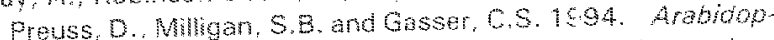
ss floral homeotc gene BELL $1 B E$ I controli ovule develop ment through negave regulaton of aGAMOUS gene $(A G)$ Pros. Natl. Acad Soi USA 91:5761 576E.

Rivera-Pomar, P., ku, $X$. Permon. N., Tubert. H. and Jackle. H. 1995. Actuation of posterior gap gene expres sion in the orophila blastodem. Nature 76 : $253-256$.

Rof, D.A. 1994. Optmalry modeling and quntitatye gener cs a comparison of the wo approches. /f: Boake, C.R. $\mathrm{B}$ (ed. Quantative Genetic Studies of Benanal Evolution. 49-60. The Unversty of Chicago Press. Chicago.

Folo. C.D. 1994. Phenowpes: that Epigenetics, Ecology and Evoluton, Chapman and Hal, London.

poth $Y$ L. 1988. The piological basis of homolog in Humphres $\mathrm{C}$. led. Ontogemy and Systematic; po. $1-26 \mathrm{Col}$ umbia Unvorsty Pess, Nev York, NY.

Salser. S... and Kenyon, 1994 . Parteming $\mathrm{C}$ elegans: horrectic duster genes. cell fates and ell migramons. Trends in Genetics 10: $159-164$.

Scharloo, W. 1988 . Selection on morpholocical patters. in. ing G ded. Population Genetics and evolution, 230 250. Springerverkg. Berin.

Schlichtha, C.O. 1986. The evolution of phenotyol plast. cty in piants. Annu Rev. Ecol. Syst. 17: $367-693$.

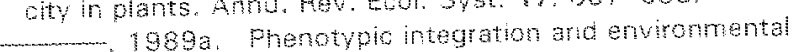

change. Sioscice $39: 460-464$

19896 . Phenotypic olasticty in Phox. II. Fasticity of character correlations. Oecologia 78 : 496-501.

and Piglucol M. 1995 . Cene regulaton, cuantitafue genetics, and the evolution of reacion noms. Evol. fool 9: $154-168$.

ㄴ...... and 1995b. Lost in phenotypic space: en vromment dependent morphology in phox drummonin Polemoniaceael. Int J. Plant 5o. 156:542-546.

Schmahasen, 1.1. 1949. Factors of Evolution. Blakiston. PMlacelphia.

Gchmid, $\mathrm{B}$. and Dor, $\mathrm{C}$. 1994 . EFeots of maternal and paternal enviroment and ganotype on oftspnng phenotye in Soldago atissma L. Evoluton 49: $1525-1549$

Schmidt K. 1994, A puzze: how similar signals vield difterent ettacts. Science 266:566-567.

Somwenk, K. 1995, A utitaran approach to evolutionary congtraint. Zooiogy $98: 252-261$.

Semitcon, R.D. Harrs, R.N. and Wibur H.M. 1990. paedomophosis in Ambystoma talooideum maintenance of poulation variation and altemathe litehistory pathways. Evolution 44: $1604-1613$

Simpson, J. van Montagu, M. and herera-Estrola, L. 1986. photosymhesis-associated geno famlles; dherences in response to tissue-spechlo and emiromantal factors. science $233: 34-36$.

Slatin M. 1987 . Quantitative genetics of heterochony. Evolution 4 : $799-311$

Smingil. S.1. 1983. Developmenta plasticity davelop mentel comversion versus pherotypic modulaton. Am. 200. 23:47-55.

Sordino, Fen der toeven, F. and Duboule, D. 1995 . Hox gene expresson in teleost fins and the origh of vertebrate digits. Mature $375: 679-881$.

steams, S.6. 1982 . The role of development in the evolution ofllehistones. Im. Bonner, J.T. Led.). Evolution and Devatopment, $237-258$. Springer-Verlog. New York.

ment, $237-238$. Thenger interface of life-history evolution, whole organiam ontogeny and guantitative genetics. Am. zool. $23:-125$

1989. The evolutionary signfleance of phenotypic plasticity. Blosclence 39:438-445.

plastity. Jon $G$ and Mewman, $B$. 1991. The effects of phenotyolc plasticity ongenetic coralations. Trends in Ecolog and Evolution b: $122-126$.

Stebbins J. G.L. 1950 . Variation and Evolution in Powerng Piants. Columbis Unversity Press. New York.

Strauss. R. 1990. Heterochronic variation in the developmental timing of cranal osstications in poesind fishes Cyprinodontifomes). Evolution 44: $1558-1567$

Sutan, $8.2 .198 \%$. Evolutonary implications of phenotypic plasticty parts. Evol. Biol. 2 : $127 \ldots 178$.

Thomas, J.1, 1993. Thinking about genete refundancy. Trends in Generics 9 : $395-399$.

Thompson, D.8. 1902 . Consumption mates and the evoluton of der induced plasticty in the head morphology of Melanophs fomurubim Iothoptera Acrididat. oeclogis $89: 204213$

Turell M. 1988. Phenotypic evolution constant covar. ances and he naintenance of additve variance. Evoluton $42: 1342-134 \%$

an Tenderen. F.H. and Antonovics 1. 1994 Consraints in 
evolution: on the baby and the bath water. Func. Eol. 8 : $139-140$

Va. 5.1987 . Genetic constrants on the evolution of pheno-

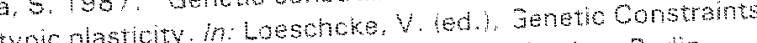

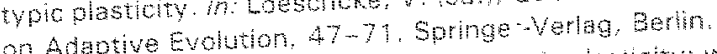

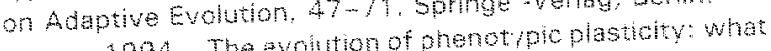
1994. The evolution of phenothic plashory whot do we realy know? in: Real, L. Eded foolog

35-57, Princeton Univisty Press, Priceton. Wadington. C.H. 1942. Canalizaton th development and

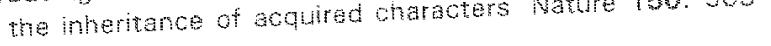
565

402 Selection of the genetic basis for an acqured character. Nature 169:278.

1353 cenetic assmidation of an acouired chande ter, Evoluton 7: $119 \times 126$

London. 1957 The Srategy of the Stres. Allen 8 Unwin

. Comolion of develochentand genstic as 1959. Candhaton of develofment and gonotic

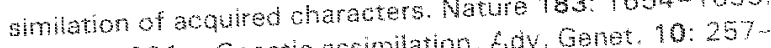
290 .

290. G. 1988 . The significarce of developmental con

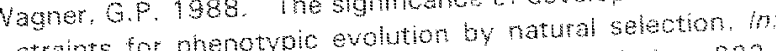
strints for phenotyplo evoluton by nawal selection, 22 Jong. G.d. led. Population Genetios and Evoluton, 22229. Springer-veriag. Benln.

Waren RW. Nay, L. Selegue, J. Gres, h. and Garroll, $\mathrm{S}$ aren

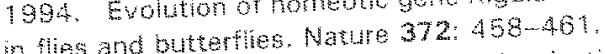

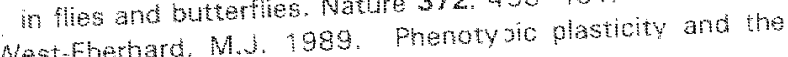
Feceived May 1, 1995. Accopted August 30, 1996. orighs of dversity Ann. Rev of Ecol Syst $20: 249-278$. Whiams, JA, Padock, S.W. Vowek, K. and Carroll, S.B. 1994 organization of wha fomation and inducton of a oreme dorsalventral comparmenz

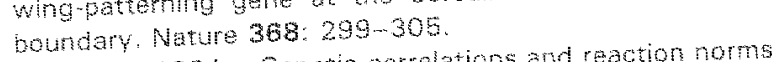

Whdig. J. 1994. Genetc correlations and reation nom in wing patam of the troplcal buterfly bicychs anyana Heredty $73: 459-470$

Wolpat 1994 bo we understend develooment? Science 266: $571 \cdots 672$.

Wotareck F 1909 . Weiterer expermentele Untersuchunqen Wor Arveranderunc Spezell uber das wessen

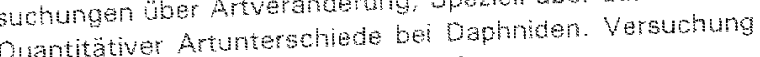
Oeutach Zool. Gesell., 19: 110-172.

Deutsch zool. Gesel., 19 . 110 f Wray, S.A. 1992 . The evolution of tarvan morphogy during the post-paleozoic radiation of echnots. Pateoblobsy $258-287$

- 1995 . Pnchuted evoluton of embryos. Science 267: 1115\%1116.

and Mociay, D. P. 1989. Molecular heremochonas and heremoples in early ehinold development. Evoluton 43: $803-813$

par RR. 1991 The evolution of devalop. mental strateoy mane invertebrates. Trends in Ecology and Evolution $45-60$.

alitoh M. 1988. Ontogenetc variation in patterns of phe notypic ingatom in the laboratory rat. Evolution 42: 28 -4 i. 